\title{
ANALISIS PENDAPATAN DAN KONSUMSI MASYARAKAT PESISIR PANTAI (Studi Kasus: Di Dusun Rarumis Desa Karor Kecamatan Lembean Timur)
}

\author{
Mianty Pangerapan \\ O. Esry. H. Laoh \\ Ellen G. Tangkere
}

\begin{abstract}
The study aims to determine the income and consumption of coastal communities in Rarumis hamlet eastern sub-district of Lembean. The data used are primary data and secondary data. Primary data were obtained by using direct interview of technique on respondents by using questionnaire (questionnaire). While secondary data is obtained from Karor village office of eastern sub-district of Lembean. Sample method in this study used population method where sampling or data taken as a whole. The concept of meansurement of variables used in household consumption and income levels. The result of this research shows that Hamlet Rarumis Districts of eastern daienan there are two income from society that is basic income as farmer obtained by result of plant of chili, corn, coconut and side income as farm laborer working in owned land of others, as fisherman doing fish at sea for sale in other villages, as well as small businesses by opening stalls. Income that the perolwh community is used to meet the consumption of each family through the expenditure of primary, secondary and tertiary needs.
\end{abstract}

Keywords: income analysis, consumption, coastal communities, Rarumis hamlet, Karor village. sub-district of Lembean

\begin{abstract}
ABSTRAK
Penelitian ini bertujuan untuk mengetahui pendapatan dan konsumsi masyarakat pesisir pantai di Dusun Rarumis Kecamatan Lembean Timur. Data yang digunakan yaitu data primer dan data sekunder. Data primer diperoleh dengan menggunakan teknik wawancara langsung pada responden, dengan menggunakan daftar pertanyaan (kuesioner). Sedangkan data sekunder di peroleh dari Kantor Desa Karor Kecamatan Lembean Timur. Metode pengambilan sampel dalam penelitian ini menggunakan metode populasi dimana pengambilan sampel atau data diambil secara keseluruhan. Konsep pengukuran variabel yang digunakan adalah konsumsi rumah tangga dan tingkat pendapatan. Hasil penelitian ini menunjukan bahwa Dusun Rarumis Kecamatan Lembean Timur terdapat dua pendapatan dari masyarakat yaitu pendapatan pokok sebagai petani yang di peroleh melalui hasil tanaman rica, jagung, kelapa dan pendapatan sampingan sebagai buruh tani yang bekerja dilahan milik orang lain, sebagai nelayan yang melakukan penangkapan ikan dilaut untuk dijual di desa-desa lain, serta usaha kecil-kecilan dengan membuka warung. Penghasilan yang masyarakat peroleh digunakan untuk memenuhi konsumsi setiap keluarga melalui pengeluaran kebutuhan primer, sekunder dan tersier.
\end{abstract}

Kata kunci: analisis pendapatan, konsumsi, masyarakat pesisir pantai, dusun Rarumis, Desa Karor, Kecamatan Lembean Timur. 


\section{PENDAHULUAN}

\section{Latar Belakang}

Sektor pertanian memiliki peranan yang penting dalam pembangunan perekonomian nasional diantaranya dalam pembentukan PDRB, penyerapan tenaga kerja, pembangunan ekonomi daerah, ketahanan pangan, dan dalam pelestarian lingkungan hidup. Sektor pertanian terdiri dari sub sektor tanaman pangan yang meliputi padi, palawija dan hortikultura, serta sub sektor tanaman perkebunan. Dari keempat sub sektor tersebut hortikultura merupakan salah satu bagian dari sektor pertanian yang dapat dijadikan sumber pertumbuhan ekonomi (Nadhwatunnaja, 2008).

Dalam melakukan kegiatan sehari-hari manusia tidak akan terlepas dari kegiatan konsumsi. Konsumsi merupakan kegiatan membelanjakan pendapatan untuk berbagai macam barang dan jasa guna memenuhi segala kebutuhan manusia, baik itu untuk kebutuhan jasmani maupun rohani seperti makan, minum, pendidikan, kesehatan, hiburan dan kebutuhan lainnya. Hal ini menunjukan bahwa konsumsi merupakan salah satu penggerak dalam kegiatan perekonomian (Mulyani, 2015).

Struktur ekonomi Indonesia saat ini telah mengalami transformasi di mana perekonomian negara saat ini lebih ditopang pada sektor industri dan jasa. Meskipun demikian, sektor pertanian nampaknya masih menjadi salah satu sektor dalam struktur ekonomi negara yang tidak dapat dikesampingkan. Selain dibutuhkan sebagai penyediaan pangan nasional, sektor pertanian juga menyerap sebagian tenaga kerja nasional. Hingga saat ini sektor pertanian masih menjadi tumpuan hidup bagi sebagian besar angkatan kerja di Indonesia (Nawawi, 2014).

Di Kabupaten Minahasa, khususnya Dusun Rarumis Desa Karor Kecamatan Lembean Timur merupakan salah satu desa yang mengembangkan kegiatan usahatani seperti cengkih, kelapa, cabe, jagung, pisang, kacang tanah. Desa karor memiliki 5 (lima) dusun salah satunya dusun 5 (lima) yang terdapat di Pesisir Pantai Rarumis.
Masyarakat yang tinggal di pesisir pantai tersebut adalah masyarakat dusun jauh dengan jumlah penduduk 40 jiwa, dan pemerintah menyiapkan lahan untuk mereka tinggal dan pemerintah menyediakan fasilitas seperti Gereja dan Sekolah.

Walaupun masyarakat ini tinggal di pesisir pantai, tetapi pekerjaan mereka sebagian besar adalah bertani, dan ada juga sebagai buruh tani, nelayan hanya pekerjaan sampingan. Dilihat dari pandangan tersebut masyarakat yang berada di pesisir pantai masih termasuk miskin, karena pendapatan tidak menetap sehingga mempengaruhi konsumsi.

Berdasarkan uraian diatas tersebut menimbulkan ketertarikan untuk melakukan penelusuran lebih jauh tentang pendapatan dan konsumsi masyarakat yang berada di pesisir pantai rarumis.

Walaupun masyarakat ini tinggal di pesisir pantai, tetapi pekerjaan mereka sebagian besar adalah bertani, dan ada juga sebagai buruh tani, nelayan hanya pekerjaan sampingan. Dilihat dari pandangan tersebut masyarakat yang berada di pesisir pantai masih termasuk miskin, karena pendapatan tidak menetap sehingga mempengaruhi konsumsi.

Berdasarkan uraian diatas tersebut menimbulkan ketertarikan untuk melakukan penelusuran lebih jauh tentang pendapatan dan konsumsi masyarakat yang berada di pesisir pantai rarumis.

\section{Rumusan Masalah}

Berapa pendapatan dan konsumsi masyarakat Pesisir Pantai Rarumis, Kecamatan Lembean Timur?

\section{Tujuan dan Manfaat Penelitian}

Tujuan dari penulisan ini adalah untuk mengetahui pendapatan dan konsumsi Masyarakat Pesisir Pantai Rarumis, Kecamatan Lembean Timur. Penelitian ini diharapkan dapat memberikan manfaat yaitu menambah wawasan dan memberikan informasi mengenai keadaan pendapatan dan konsumsi masyarakat pesisir pantai Rarumis. 


\section{METODOLOGI PENELITIAN}

\section{Lokasi dan Waktu Penelitian}

Penelitian ini dilakukan di Dusun Rarumis, Kecamatan Lembean Timur. Waktu penelitian yakni dimulai pada bulan April sampai bulan Juli 2017.

\section{Metode Pengumpulan Data}

Data yang digunakan adalah data primer dan sekunder. Data primer di peroleh dengan menggunakan teknik wawancara langsung pada responden, dengan menggunakan daftar pertanyaan (kuesioner). Sedangkan data sekunder di peroleh dari kantor Desa Karor Kecamatan Lembean Timur.

\section{Metode Pengambilan Sampel}

Penentuan lokasi pengambilan sampel yaitu di Dusun Rarumis Kecamatan Lembean Timur. Metode pengambilan sampel dalam penelitian ini menggunakan metode populasi dimana pengambilan sampel atau data diambil secara keseluruhan yaitu berjumlah $15 \mathrm{KK}$.

\section{Konsepsi Pengukuran Variabel}

Adapun Variabel yang di ukur dalam penelitian ini adalah :

1. Konsumsi Rumah Tangga yaitu besarnya pengeluaran untuk makanan dan bukan makanan ditunjukkan dalam nilai rupiah per bulan.

2. Tingkat Pendapatan yaitu pendapatan yang diterima oleh rumah tangga diukur dengan rupiah per bulan terdiri dari :

a) Pendapatan Pokok, yaitu pendapatan yang diterima oleh rumah tangga dari pekerjaan pokok dalam rupiah per bulan.

b) Pendapatan Sampingan, yaitu pendapatan yang diterima oleh rumah tangga dari pekerjaan sampingan dalam rupiah per bulan.

\section{Analisis Data}

Analisis data yang digunakan dalam penelitian ini adalah analisis deskriptif untuk mengetahui pendapatan dan konsumsi masyarakat pesisir pantai di Dusun Rarumis Desa Karor.

\section{HASIL DAN PEMBAHASAN}

\section{Deskripsi Lokasi Penelitian}

\section{Letak Geografis}

Desa Karor adalah salah satu Desa di Kecamatan Lembean Timur yang memiliki lima dusun. Dusun Rarumis merupakan dusun jauh yang berada di pesisir pantai berjarak $\pm 7 \mathrm{~km}$ dengan lahan $450 \mathrm{Ha}$ di ketinggian $200 \mathrm{Mdpl}$ (meter diatas permukaan laut). Kecamatan Lembean Timur berada di Kabupaten Minahasa Provinsi Sulawesi Utara.

\section{Keadaan Dusun Rarumis Kecamatan Lembean Timur}

Desa Karor merupakan salah satu Desa yang ada di Kecamatan Lembean Timur yang teridiri dari 5 (lima) dusun dengan akses jalan antar dusun yang lumayan jauh. Dusun Rarumis merupakan dusun kelima yang memiliki jarak paling jauh dibandingkan dengan dusun lain. Untuk menjangkau dusun kelima, harus menempuh waktu \pm 30 menit dengan menggunakan kendaraan beroda dua atau empat untuk sampai dusun tersebut. Karena lokasi Dusun Rarumis berada tepat di daerah pesisir pantai. Topografi daerah berbukit dan sedikit pegunungan.

Lahan yang berada di Dusun Rarumis merupakan lahan milik pemerintah yang diserahkan secara gratis kepada masyarakat Desa Karor untuk dijadikan tempat tinggal dan tempat pemanfaatan peningkatan potensi pendapatan masyarakat sekitar. Aktivitas ekonomi penduduk di dominasi dengan sektor pertanian dan perkebunan, sebagian besar lahan yang ada digunakan oleh petani untuk melakukan kegiatan usaha tani seperti menanam rica, jagung, kelapa dan cengkih, kacang tanah, pisang yang dijadikan sebagai sumber pendapatan oleh masyarakat pesisir pantai di Dusun Rarumis. Berikut ini adalah gambar lahan yang ada di Dusun Rarumis Desa Karor. 


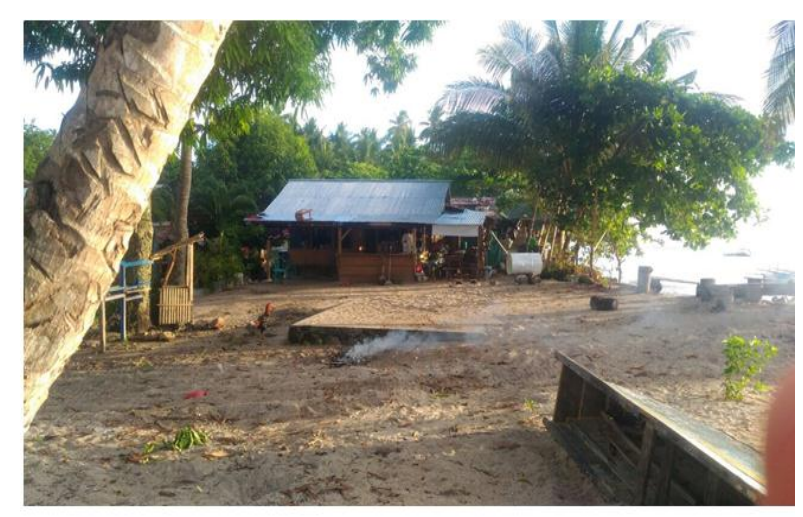

Gambar 1. Lahan Dusun Rarumis Desa Karor Kecamatan Lembean Timur

Berdasarkan gambar 1 dapat dilihat bahwa di Dusun Rarumis memiliki lahan dan pantai. Masyarakat membangun beberapa tempat tinggal yang mimiliki jarak yang dekat dengan pantai sehingga ketika ada pengunjung atau wisatawan yang baru pertama kali datang di Dusun Rarumis Desa Karor tidak segan menginap dirumah warga untuk menikmati keindahan pantai di pagi hari.

Dusun Rarumis terletak jauh dari pusat kota sehingga apabila masyarakat membutuhkan keperluan sehari-hari, mereka harus mendapatkannya di pasar Langowan dengan akses jalan yang membutuhkan waktu 60 menit untuk sampai di pasar Langowan. Berikut ini adalah gambar jalan akses menuju Dusun Rarumis.

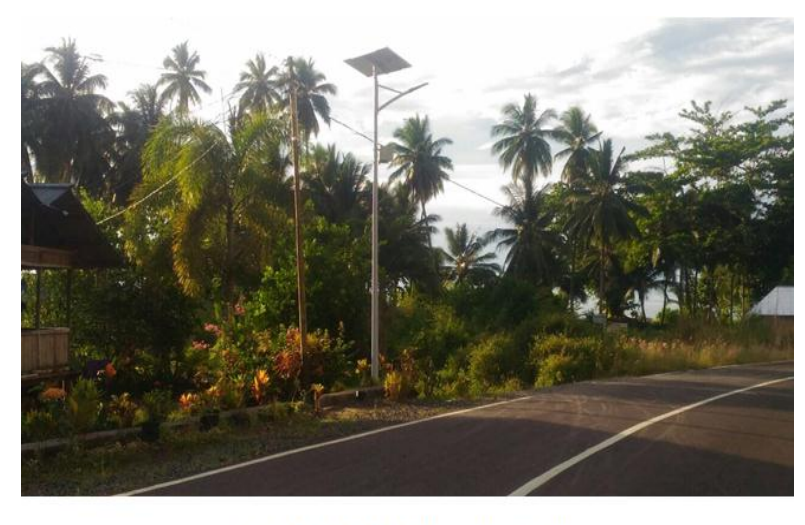

Gambar 2. Jalan Dusun Rarumis

Dapat dilihat pada gambar 2 bahwa akses jalan untuk bisa mencapai Dusun Rarumis sangat baik karena keadaan jalan sudah di aspal, sehingga semua kendaraan yang ada bisa digunakan untuk tiba di Dusun Rarumis.
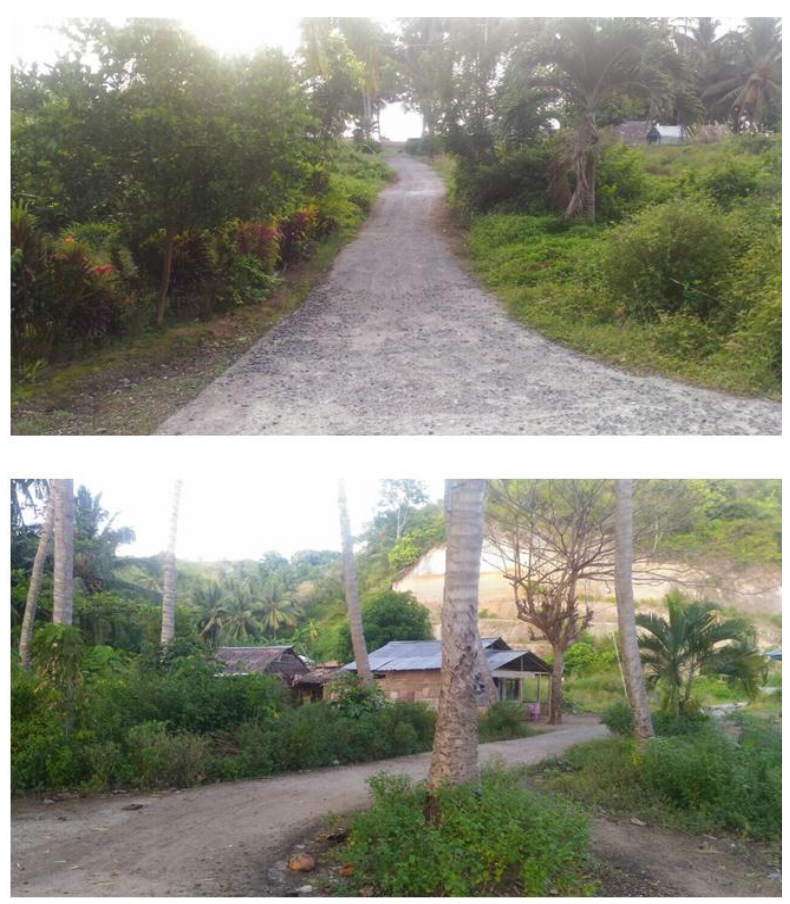

Gambar 3. Jalan Lorong Dusun Rarumis

Berdasarkan gambar 3, dapat dilihat bahwa jalan lorong yang ada di Dusun Rarumis sudah bisa di akses oleh kendaraan beroda dua dan empat.

Semua masyarakat yang tinggal di pesisir pantai Dusun Rarumis memiliki keyakinan yang sama yaitu beragama Kristen karena semua penduduk berasal dari Desa Karor. Interaksi sosial masyarakatnya baik dan tenggang rasa antar warga sangatlah tinggi. Berikut ini adalah gambar Gereja yang ada di Dusun Rarumis.

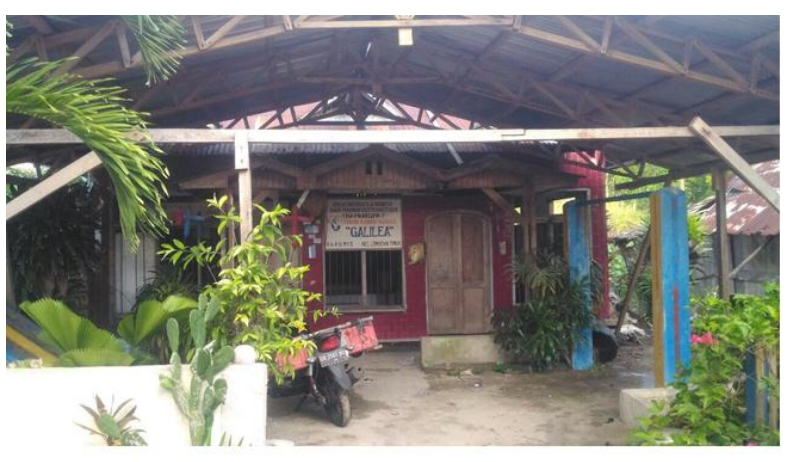

Gambar 4. Gereja Pantekosta di Dusun Rarumis

Berdasarkan gambar 4 dapat dilihat bahwa di Dusun Rarumis sudah memiliki Gereja yaitu Gereja Pantekosta, yang menjadi tempat beribadah bagi masyarakat. Disamping itu, Gereja ini juga digunakan sebagai taman kanak-kanak bagi anak-anak yang ada di dusun tersebut. 


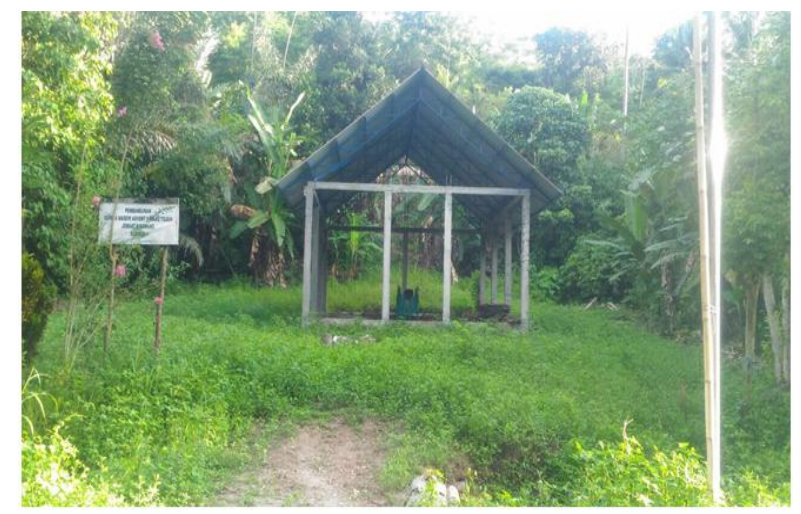

Gambar 5. Gereja Advent di Dusun Rarumis

Berdasarkan gambar diatas, dapat dilihat bahwa Gereja Adevent merupakan gereja kedua yang ada di Dusun Rarumis. Saat ini Gereja masih sementara dalam pembangunan, namun jemaat Advent sudah menggunakan gedung ini untuk tempat beribadah.

Kondisi tempat tinggal masyarakat yang ada di Dusun Rarumis masih menggunakan atap katu dengan dinding kayu yang berlantaikan tanah. Namun ada beberapa rumah yang sudah memiliki atap seng. Ada pula yang masih menggunakan dinding bambu. Berikut ini adalah gambar rumahrumah yang ada di Dusun Rarumis.

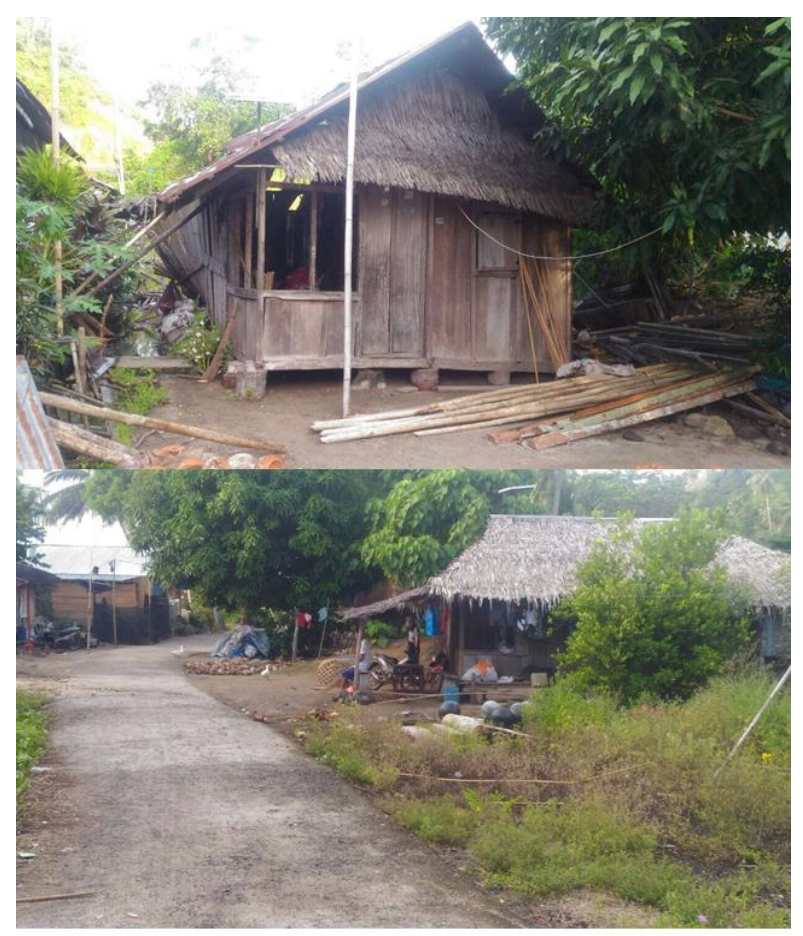

Gambar 6. Rumah Atap Katu di Dusun Rarumis

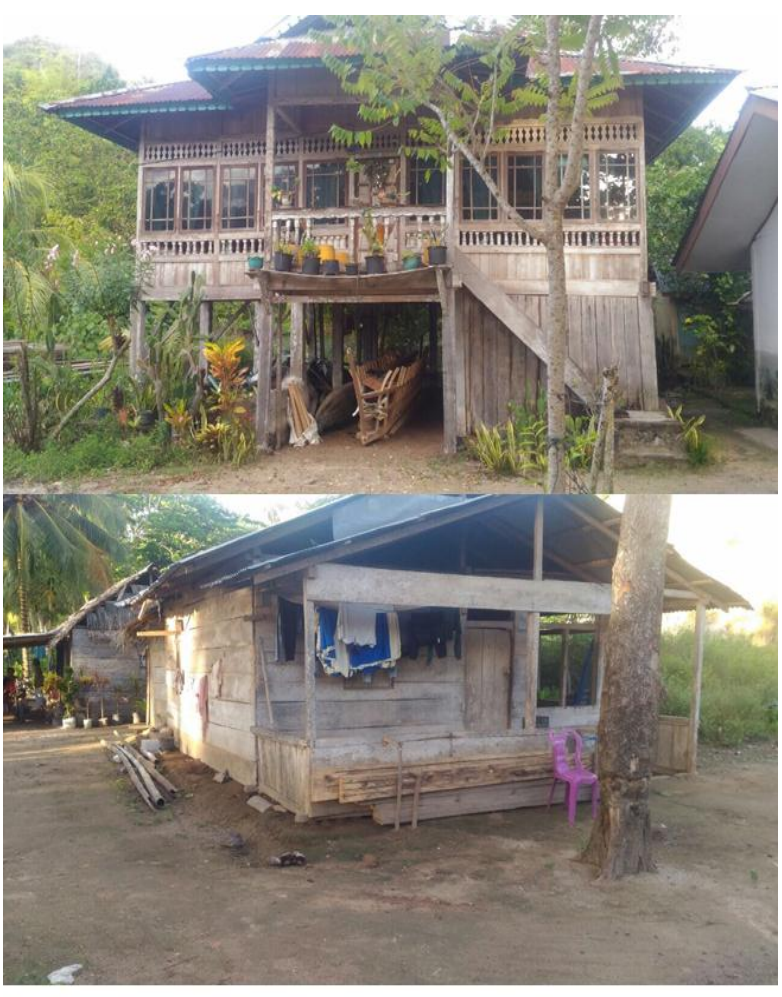

Gambar 7. Rumah Atap Seng di Dusun Rarumis

Berdasarkan gambar enam dan tujuh, di Dusun Rarumis masih terdapat empat rumah yang masih memiliki atap katu dan sebelas rumah yang sudah memiliki atap seng dengan dinding kayu.

\section{Keadaan Penduduk}

Penduduk di Dusun Rarumis berjumlah 40 jiwa, dengan jumah penduduk laki-laki sebanyak 23 jiwa dan jumah perempuan sebanyak 17 jiwa. Keluarga di Dusun Rarumis berjumlah $15 \mathrm{KK}$.

\section{Mata Pencaharian Penduduk}

Tingkat perekonomian masyarakat Dusun Rarumis termasuk golongan ekonomi lemah, karena sebagian besar masyarakat berprofesi sebagai petani yang tidak mempunyai tanah pertanian sendiri atau buruh tani. Selain itu SDM dari masyarakat yang masih rendah menyebabkan tingkat keberhasilan usaha-usaha menjadi rendah. Jumlah penduduk yang bekerja menurut mata pencaharian di Dusun Rarumis dapat di lihat pada tabel berikut ini: 
Tabel 1. Jenis Mata Pencaharian Penduduk

\begin{tabular}{|c|c|c|}
\hline $\begin{array}{c}\text { Mata } \\
\text { Pencaharian }\end{array}$ & $\begin{array}{l}\text { Jumlah } \\
\text { (Orang) }\end{array}$ & $\begin{array}{c}\text { Persentase } \\
(\%)\end{array}$ \\
\hline Petani & 10 & 33,33 \\
\hline Buruh Tani & 8 & 26,67 \\
\hline Nelayan & 8 & 26,67 \\
\hline Pedagang & 4 & 13,33 \\
\hline Total & 30 & 100 \\
\hline
\end{tabular}

Sumber: Kantor Desa Karor, 2017

Tabel 1 menunjukkan bahwa mata pecaharian penduduk Dusun Rarumis serta presentase masing-masing pencaharian. Dari Tabel 1 dapat dilihat bahwa jenis mata pencaharian yang paling tinggi ada pada tingkat petani yaitu sebanyak 10 orang dengan presentase sebanyak 33,33\% sedangkan pedagang memiliki presentase paling sedikit yaitu $13,33 \%$.

\section{Karakteristik Responden}

Dalam pengambilan sampel responden di Dusun Rarumis, di ambil secara keseluruhan (populasi) dengan jumlah 15 responden. Adapun yang di maksud dengan karakteristik responden terdiri dari umur, tingkat pendidikan, tanggungan keluarga.

\section{Umur Responden}

Umur responden akan mempengaruhi produktifitas dalam bekerja atau peranannya dalam proses pengambilan keputusan diberbagai alternative pekerjaan yang dilakukan. Umur Responden akan mempengaruhi seseorang untuk bekerja secara fisik serta menentukan cara berpikir. Cara berpikir dan kemampuan fisik sangat dipengaruhi oleh tingkat umur. Semakin tinggi umur makin berkurang kemampuan dalam bekerja, sedangkan yang berumur muda pada umumnya mempunyai kemampuan fisik yang lebih baik. Tingkat umur dari responden dapat dilihat dalam Tabel 2.

\begin{tabular}{ccc} 
Tabel 2. Jumlah Responden Menurut Umur Responden \\
\hline $\begin{array}{c}\text { Umur } \\
\text { (Tahun) }\end{array}$ & $\begin{array}{c}\text { Jumlah } \\
\text { Responden }\end{array}$ & $\begin{array}{c}\text { Persentase } \\
(\%)\end{array}$ \\
\hline $35-45$ & 2 & 13,33 \\
$46-50$ & 4 & 26,66 \\
$51-60$ & 6 & 40,00 \\
$61-71$ & 3 & 20,00 \\
\hline Jumlah & 15 & 100
\end{tabular}

Sumber : Diolah dari data primer, 2017
Tabel 2 menunjukkan bahwa responden yang berumur 35-45 tahun adalah yang paling sedikit yaitu 2 orang atau $13,33 \%$ dari keseluruhan responden, sedangkan responden jumlah terbanyak adalah yang berumur 51-60 tahun yaitu sebanyak 6 orang atau 40,00\%.

\section{Tingkat Pendidikan}

Pendidikan merupakan salah satu hal yang penting bagi manusia yang merupakan bekal dalam hidupnya. Karena dengan pendidikan yang cukup seorang akan memiliki pola pikir yang lebih maju dan berkembang. Berdasarkan hasil penelitian, tingkat pendidikan responden bervariasi, mulai dari tingkat Sekolah Dasar (SD), Sekolah Menengah Pertama (SMP), dan Sekolah Menengah Atas (SMA), dapat di lihat di Tabel 3.

Tabel 3. Jumlah Responden Menurut Tingkat Pendidikan

\begin{tabular}{lcc}
\hline $\begin{array}{c}\text { Umur } \\
\text { (Tahun) }\end{array}$ & $\begin{array}{c}\text { Jumlah Responden } \\
\text { (Orang) }\end{array}$ & $\begin{array}{c}\text { Persentase } \\
(\%)\end{array}$ \\
\hline SD & 9 & 60,00 \\
SMP & 3 & 20,00 \\
SMA & 3 & 20,00 \\
\hline Jumlah & 15 & 100 \\
\hline
\end{tabular}

Sumber : Diolah dari data primer, 2017

Tabel 3 menunjukkan bahwa responden sebagian besar memiliki pendidikan formal SD dengan jumlah responden 9 orang, sedangkan untuk tingkat SMP berjumlah 3 orang dan SMA berjumlah 3 orang dan tidak ada responden yang memiliki pendidikan formal perguruan tinggi. Berarti bahwa ada $60,00 \%$ berpenddikan SD, $20,00 \%$ berpendidikan SMP dan 20,00\% berpendidikan SMA.

\section{Pendapatan Pokok dan Pendapatan Sampingan Responden dalam 1 Bulan di Dusun Rarumis}

Pendapatan merupakan faktor yang sangat penting dalam menunjang perekonomian keluarga. Tingkat pendapatan merupakan salah satu indikasi sosial ekonomi seseorang dalam masyarakat di samping pekerjaan, kekayaan dan pendidikan. Tinggi rendahnya pendapatan tergantung pada hasil pertanian dan biaya konsumsi. Jika pendapatan naik maka konsumsi juga akan naik ketika pendapatan menurun maka konsumsi juga menurun. 
Salah satu kegiatan yang dijadikan sumber pendapatan pokok oleh masyarakat Dusun Rarumis yaitu diperoleh melalui sektor pertanian seperti hasil dari tanaman rica, jagung dan kelapa. Tanaman ini penting bagi masyarakat karena dianggap sebagai salah satu sumber pendapatan pokok dari setiap petani. Melalui kegiatan pertanian ini masyarakat memperoleh keuntungan atau pendapatan sehingga dapat memenuhi akan kebutuhan hidup masyarakat dan keluarga mereka. Selain itu masyarakat di Dusun Rarumis memiliki pendapatan sampingan melalui buruh tani dengan cara bekerja dilahan orang lain dan mendapatkan upah dari pemilik lahan.

Nelayan yaitu dengan cara melakukan penangkapan ikan di laut dan dijual di desadesa lain yang ada di Kecamatan Lembean Timur, dan pedagang seperti usaha kecilkecilan dengan membuka warung, guna memenuhi kebutuhan hidup mereka. Berikut ini tabel pendapatan pokok dan pendapatan sampingan responden dalam satu bulan di Dusun Rarumis.

\begin{tabular}{lccc} 
Tabel & 4. & $\begin{array}{c}\text { Pendapatan } \\
\text { Sampingan Responden dalam } \\
\text { di Dusun Rarumis }\end{array}$ & $\begin{array}{c}\text { Pokok } \\
\text { Satu Bulan }\end{array}$ \\
\hline No. & $\begin{array}{c}\text { Pendapatan } \\
\text { Sampingan } \\
\text { (Rp/Bulan) }\end{array}$ & $\begin{array}{c}\text { Pendapatan } \\
\text { Pokok } \\
\text { (Rp/Bulan) }\end{array}$ & $\begin{array}{c}\text { Total } \\
\text { Pendapatan } \\
\text { (Rp/Bulan) }\end{array}$ \\
\hline 1 & 2.000 .000 & 400.000 & 2.400 .000 \\
2 & 1.500 .000 & 300.000 & 1.800 .000 \\
3 & 2.000 .000 & 400.000 & 2.400 .000 \\
4 & 1.900 .000 & 500.000 & 2.400 .000 \\
5 & 2.000 .000 & 400.000 & 2.400 .000 \\
6 & 1.600 .000 & 300.000 & 1.900 .000 \\
7 & 1.500 .000 & 200.000 & 1.700 .000 \\
8 & 1.900 .000 & 400.000 & 2.300 .000 \\
9 & 2.400 .000 & 150.000 & 2.550 .000 \\
10 & 1.000 .000 & 400.000 & 1.400 .000 \\
11 & 1.500 .000 & 500.000 & 2.000 .000 \\
12 & 1.900 .000 & 600.000 & 2.500 .000 \\
13 & 1.900 .000 & 300.000 & 2.200 .000 \\
14 & 1.500 .000 & 500.000 & 2.000 .000 \\
15 & 2.000 .000 & 400.000 & 2.400 .000 \\
\hline Jumlah & 26.600 .000 & 5.750 .000 & 32.350 .000 \\
\hline Rata-rata & 1.773 .333 & 383.333 & 2.156 .667 \\
\hline & & & \\
\hline & & & \\
\hline & & & \\
& & &
\end{tabular}

Berdasarkan Tabel 4 dapat dilihat bahwa pendapatan tertinggi diperoleh dari hasil pendapatan pokok dengan jumlah dalam satu bulan yaitu sebanyak Rp.26.600.000. Hal ini disebabkan karena hasil panen dari sektor pertanian pada saat itu mengalami kenaikan harga jual sedangkan pendapatan terendah berada pada pendapatan sampingan dengan jumlah yaitu Rp.5.750.000 dalam satu bulan.

\section{Konsumsi Responden dalam 1 Bulan di Dusun Rarumis}

Pengeluaran konsumsi yang dikeluarkan oleh responden untuk memenuhi kebutuhan hidup dan keluarganya, yang berupa jenis pengeluaran kebutuhan primer, sekunder dan pengeluaran tersier. Adapun jenis pengeluaran dan rata-rata pengeluaran kebutuhan hidup masyratakat pesisir pantai Dusun Rarumis, dapat dilihat pada Tabel 5.

Tabel 5. Rata-rata Pengeluaran Konsumsi Responden dalam 1 Bulan di Dusun Rarumis

\begin{tabular}{lr}
\hline \multicolumn{1}{c}{ Jenis Pengeluaran } & Rata-rata Rp/1 Bulan \\
\hline Beras & 273.666 \\
Kopi & 22.066 \\
Susu & 56.666 \\
Ikan & 237.266 \\
Rokok & 150.133 \\
Gula & 48.866 \\
Perlengkapan Mandi & 75.600 \\
Minyak Goreng & 60.266 \\
Bumbu Masak & 104.333 \\
Jajan Anak & 116.000 \\
Bensin & 95.800 \\
\hline Jumlah & 1.240 .662 \\
\hline
\end{tabular}

Tabel 5 menunjukkan beberapa jenis pengeluaran kebutuhan yang di belanjakan oleh responden Dusun Rarumis dalam satu bulan guna untuk memenuhi kebutuhan hidup keluarga. Dari tabel tersebut terlihat bahwa jumlah pengeluaran kebutuhan selama satu bulan adalah Rp.2.664.965. Pengeluaran tersebut merupakan jumlah dari beberapa jenis pengeluaran konsumsi untuk kebutuhan rumah tangga yang berjumlah sebelas (11) pengeluaran yang di belanjakan di Dusun Rarumis. 


\section{KESIMPULAN DAN SARAN}

\section{Kesimpulan}

Berdasarkan hasil penelitian dapat disimpulkan bahwa masyarakat yang ada di pesisir Pantai Dusun Rarumis masih termasuk ekonomi lemah yang belum layak, karna pendapatan yang mereka peroleh belum dapat memenuhi keinginan dan konsumsi mereka.

\section{Saran}

Hasil penelitian ini sebaiknya dapat dijadikan acuan bagi pemerintah desa dalam rangka menentukan kebijakan apa yang cocok bagi masyarakat untuk meningkatkan kesejahteraan kehidupan masyarakat yang ada di pesisir pantai dan juga dapat melakukan pengembangan secara lebih luas.

\section{DAFTAR PUSTAKA}

Mulyani. 2015. Pola Konsumsi Non Makanan Mahasiswa Program Studi Pendidikan Ekonomi (Jurnal). Fakultas Ekonomi Universitas Negeri Yogyakarta. Diakses tanggal 22 Maret 2017.

Nadhwatunnaja, N. 2008. "Analisis Pendapatan Usaha Tani dan Faktor-Faktor Yang Mempengaruhi Produksi Paprika Hidroponik Di Desa Langu Kecamatan Cisarua" (Skripsi). Fakultas Pertanian Bogor. Diakses tanggal 18 Januari 2017.

Nawawi. 2014. Analisis Pendapatan Dan Kelembagaan Usahatani Lahan Pantai di Desa Garongan Kecamatan Panjatan Kabupaten Kulon Progo (Jurnal). Fakultas Ekonomi Dan Manajemen Institut Pertanian Bogor. Diakses tanggal 8 Februari 2017. 